\title{
INFLUENCE OF THE SUBSTRATE IN GERMINATION OF LYCHEE SEEDS ${ }^{1}$
}

\author{
RENATA APARECIDA DE ANDRADE², ANTONIO BALDO GERALDO MARTINS ${ }^{3}$, \\ INEZ VILAR DE MORAIS OLIVEIRA ${ }^{4}$
}

\begin{abstract}
The lychee is, all over the world, considered as the "queen of the fruits" due to the delicacy of its appearance and flavor. Although it was only recently that it started to have economical importance in Brazil, the lychee is already calling the attention of numerous farmers, mainly those who cultivate citric fruits and/or sugarcane in the State of São Paulo, due to the constant and at the same time growing necessity of finding new alternative crops. Considering that the commercial cultivation of lychee plants in the field requires the previous obtainment of rootstocks viewing to reduce the genetic variability and the length of the juvenile period displayed by plants resulting directly from the seeds, finding ways to improve the germination performance of lychee seeds for the production of rootstock plants is of considerable economic importance. Thus, the objective of this experiment was to test five substrates for the germination of lychee seeds: (1) vermiculite, (2) washed sand, (3) filter paper, (4) carbonized rice hull, and (5) sphagnum. The results showed that the period of time required by a lychee seed to germinate is a short one thus reinforcing the importance of providing a suitable substrate for the germination to take place. It was found that the substrates which apparently allowed the best combinations of water and oxygen availability for the seeds - washed sand and carbonized rice hull - were those leading to the fastest and highest germination values. Index terms: Litchi chinensis Sonn.; seeds; germination
\end{abstract}

\section{INFLUÊNCIA DO SUBSTRATO NA GERMINAÇÃO DE SEMENTES DE LICHIA}

RESUMO - A lichia é considerada em todo o mundo como a rainha das frutas, por sua aparência e sabor delicado. Atualmente, a cultura vem despertando interesse, principalmente no Estado de São Paulo, onde, em virtude dos problemas enfrentados pelos agricultores, destacando-se os de laranja e cana-de-açúcar, a procura por alternativas agrícolas vem se intensificando ainda mais.

A propagação através de sementes não é recomendada comercialmente, pois as plantas de pé-franco são geneticamente muito desuniformes e apresentam período juvenil muito longo, demorando até 10 anos para entrar em produção; no entanto, a semente pode ser utilizada para a obtenção de porta-enxertos. Observou-se que a germinação de sementes de lichia ocorre rapidamente, reforçando a importância do uso de um substrato adequado. Pela análise dos resultados obtidos, verifica-se que o substrato que aparentemente permitiu as melhores combinações de água e disponibilidade de oxigênio para as sementes - casca de arroz carbonizada e areia lavada, foi o que proporcionou valores de germinação mais rápidos e mais altos.

Termos para indexação: Litchi chinensis Sonn.; sementes; germinação.

The lychee ( Litchi chinensis, Sonn.) is, all over the world, considered as the "queen of fruits" due to the delicacy of its appearance and flavor. Its fruit, in addition to being very rich in mineral salts and vitamins, has a delicious flavor. Although its introduction in Brazil is known to have taken place in 1810 (Martins et al., 2001), it was only a few years ago that its economical importance started to grow mainly as an alternative crop for farmers having technical and economical problems with citrus and/or sugar cane crops.

The commercial propagation of lychee is carried out by means of vegetative processes, the air-layering one being the most commonly employed, although other processes (such as direct seed sowing, grafting, cutting, etc.) may as well be employed (Donadio et al., 1992). But the grafting method, due to its requiring less tissue from the matrix plant, is recognized to be less invasive and thus significantly less damaging to the matrix plant than the air-layering method. In addition to that, the grafting method has the following additional advantages over the air-layering method: 1) it allows a considerably higher number of propagules per plant and 2) the resulting plantlet has a much deeper and larger root system to start with since it makes use of the rootstock root system and this leads to a better and faster plant establishment in the field.

The direct seed sowing method is also disadvantageous from the economical point-of-view due to the following reasons as pointed out by Meletti \& Coelho (2000): 1) the plants show very high genetic variability; 2) the juvenile period of the plants is very long; 3 ) it takes up to 10 years for the plants to start producing economical yields; 4) the yields exhibit yearly alternation; and 5) the fruits are of inferior quality.

The grafting method demands plants which will function as rootstocks, these plants being the result of seeds germination. Having this in mind this work investigated 5 types of substratum in order to find out which would allow higher and faster seed germination.

The experiment was conducted at the Seed Laboratory, located in the Department of Vegetable Production of Faculdade de Ciências Agrárias e Veterinárias - UNESP - Campus of Jaboticabal, in São Paulo state.

The treatments consisted of the following substrates for seed germination : (1) vermiculite; (2) washed sand; (3) filter paper; (4) carbonized rice hull; and (5) sphagnum. Each one of these treatments were replicated 4 times and each replication had 21 seeds.

The seeds were extracted from mature fruits, washed, rinsed and set to dry under room temperature. After that they were sown in small plastic boxes $(11,5 \times 11,5 \times 3,5 \mathrm{~cm})$ containing the aforementioned substrates. These boxes were then placed inside seed germinating chambers according to a complete random design, with the temperature adjusted to a constant value of $25^{\circ} \mathrm{C}$. Seedling evaluation started 2-3 days after test installation with counts being daily made. All seeds which showed primary root protrusion were counted. The results were grouped in four blocks thus showing the total germination after each 7 day period. The Tukey test was used to compare the treatment means at the $5 \%$ level of probability.

The analysis of the results (Table 1) shows that the highest germination percentages were verified to occur when the carbonized rice hull substrate was employed. A week after the germination test had been installed the seeds sown in the rice hull substrate had already reached what seemed to be very close to the maximum germination value $(83,33 \%)$, significantly superior to the values obtained for the sphagnum $(69,05 \%)$ and filter paper $(28,57 \%)$.

Although washed sand and sphagnum showed good results

\footnotetext{
${ }^{1}$ (Trabalho 101/2003). Recebido:04/09/2003. Aceito para Publicação: 29/08/2004.

${ }^{2}$ Eng. Agr., Msc. Aluna de Pós-Graduação em Agronomia - Programa de Produção Vegetal - UNESP/FCAV - Departamento de Produção Vegetal. Via de acesso Prof. Paulo Donato Castellane, s/n. Jaboticabal/SP. Cep: 14884-900. Tel/Fax: (16)32092668. e-mail: reandrad@ @fcav.unesp.br. Bolsista CNPq.

${ }^{3}$ Eng. Agr., Professor Doutor - UNESP/FCAV - Departamento de Produção Vegetal. e-mail: baldo@ fcav.unesp.br

${ }^{4}$ Eng. Agr., Msc. UNESP/FCAV - Departamento de Produção Vegetal. e-mail: inezvilar@ yahoo.com
} 
TABLE 1 - Lychee seeds germination (\%) in different types of substrate.

\begin{tabular}{|c|c|c|c|c|}
\hline \multicolumn{5}{|c|}{ Number of days after test installation } \\
\hline Substrate & 7 & 14 & 21 & 28 \\
\hline 1 - Vermiculite & $59,53 \quad \mathrm{~B}$ & $73,81 \mathrm{~A}$ & $78,57 \mathrm{~A}$ & $78,57 \mathrm{~A}$ \\
\hline 2 - Washed sand & $73,81 \mathrm{AB}$ & $73,81 \mathrm{~A}$ & $73,81 \mathrm{~A}$ & $73,81 \mathrm{~A}$ \\
\hline 3 - Filter paper & $28,57 \quad \mathrm{C}$ & $48,81 \quad B$ & $48,81 \quad B$ & $50,00 \quad \mathrm{~B}$ \\
\hline 4 - Carbonized rice hull & $83,33 \mathrm{~A}$ & $85,71 \mathrm{~A}$ & $85,71 \mathrm{~A}$ & $85,71 \mathrm{~A}$ \\
\hline 5 - Sphagnum & $69,05 \mathrm{AB}$ & $69,05 \mathrm{~A}$ & $69,05 \mathrm{~A}$ & $69,05 \mathrm{~A}$ \\
\hline
\end{tabular}

Averages following by the same letter do not differ in statistic test of Tukey to $5 \%$ of probability.

after 7 days $(73,81 \%$ and $69,05 \%$, respectively), these values did not improve in the following days - they were maintained till the $28^{\text {th }}$ day. Vermiculite even if not permitting a good result after 7 days $(59,53 \%)$ behaved differently from washed sand and sphagnum in the sense that the germination percentage increased to $73,81 \%$ and $78,57 \%$ after 14 and 21 days respectively.

The lowest germination results were those found when filter paper was used as substrate. This is thought to be due to the fact that the contact between the seeds and that substrate was not very good and this led to an impairment of the germination process.

Notwithstanding the fact that the carbonized rice hull gave the highest germination results these results, two weeks after the test installation, presented a statistically significant difference only when compared to those shown by the filter paper.

According to Sauco \& Menini (1987) seed germination can take place in any kind of substrate as long as it allows for a good aeration what, seemingly, is confirmed by the results of this work. The results herein reported seem also to indicate that the substrate may have a significant influence on the speed of seed germination.

The results herein reported indicate carbonized rice hull as the best substrate for the germination of lychee seeds. Although not as good as carbonized rice hull, washed sand permitted results also good.

\section{REFERENCES}

DONADIO, L.C. et al. Fruticultura Tropical. Jaboticabal: FUNEP, 1992. 268p.

MARTINS, A.B.G. et al., Lichieira (Litchi chinensis Sonn.). Jaboticabal: Sociedade Brasileira de Fruticultura. 2001. 48p. (Série Frutas Potenciais)

MELETTI, L.M.M.; COELHO,S.M.B.M. Lichieira (Litchi chinensis Sonn.). In: Propagação de Frutíferas Tropicais. Livraria e Editora Agropecuária. 2000. p.155-163.

SAUCO, V.G.; MENINI, U.G. Lychee cultivation. New York: FAO Plant Production and Protection, 1987. (paper, 83). 